Prakash Upadhyay

\title{
Research Article \\ Shattered Dreams and Stolen Childhood: A Study of Child Labour and Child Rights in Restaurants and Hotels of Pokhara, Nepal
}

\author{
Prakash Upadhyay \\ Associate Professor, Tribhuvan University, Prithvi Narayan Campus, Pokhara \\ Email:prak-socio@hotmail.com
}

\section{Article History}

Received 23 July 2019 Revised 29 September 2019 Accepted 9 November 2019

\begin{abstract}
Nepal is committed to end child labour expressed by the ratification of ILO convention and its national plan of action for children and Master Plan to end child labour. However, the 'wicked problem' of child labour is increasing at an alarming rate in urban areas. New hotels and restaurants have been opened and along with it a new way of child labour exploitation has emerged in urban centres. Most of the workers in restaurants/hotels of Pokhara are children. The employers of such business prefer child labour as they are cheap and can be easily exploited. This study attempts to determine the extent to which child labour constitutes a violation of child rights. Pedestal on theories of exploitation and structural-functionalism the study result reveals that condition of child labourers is disgraceful with a shattered dream and stolen childhood - a result of family dysfunction and child rights violation by employer that has thwarted the opportunities for healthy adulthood under a vicious cycle of deprivation, abuse and exploitation. Amid noxious relationship between child labourer and the employer, child labourers face violence and sexual harassment by employer, senior staff and customers. Heavy workload, trouncing and dragging by hair and ill-treatment are the common violence faced by child labourer. Most of the employers are ignorant of child rights. It is a paradox that child labourer is valuable for employer but the life of child labourer is worthless. Most of the child labourers are willing to rehabilitate.
\end{abstract}

Keywords: Anthropological lens, better off families, good dreams, rehabilitation

(C) The Author, published by JRCC, Janapriya Multiple Campus

\section{Introduction}

Amid the global capitalization and modernization process, a wide range of exploitation is found in almost all domains, while some of these are rooted traditionally and some are appearing as a part of drive towards development. Children are particularly vulnerable to poverty, social injustice, child labour, girl trafficking and the resulting exploitation. Child labour prevailing in Nepal and other poor countries is among one of the heinous social problems and violation of human rights. ILO (2004) states that child labour is simply the single most important of child exploitation and child abuse in the world today. A study by CWIN (2000) states that bonded child labour is found in most part of Nepal . . . children mostly from the backward castes are hired for different purposes and are used in almost all sectors like domestic, agricultural, and industrial, hotel, business etc. Many poor children turn up to urban areas with good dreams like opportunity to study in good schools, earning money, getting exposure, enjoy city life, a job security in future. Some children from the better off families run away from the houses and enter into the urban centres because of several attractions of the town. According to Nepal Child Labour Report (2008), social recognition, social attitude of taking children as the source of income, family dysfunction, death of parent, maltreatment and abuse of children by parents, lack of facilities and opportunity in rural areas

Janapriya Journal of Interdisciplinary Studies (Jjis), volume VIII, 2019 
etc. are the contributing factors of child labour. Sainju (2003) argues that most of the children are compelled to work for their mere survival, and cannot be an exception.

UNICEF (2007) states that the term child labour is often defined as work that deprives of their childhood, their potential and their dignity, and that is harmful to physical and mental development. It refers to work that are mentally, physically, socially or morally dangerous and harmful to children, interferes with their schooling, deprives them of the opportunity to attend school, obliging them to leave school prematurely; or requiring them to attempt to combine school attendance excessively with heavy work. Beside these problems, children face many physical dangers and death from forced labour (ILO/IPEC, 2006).

Nepal is a signatory of UN Convention on the Rights of the Child, Convention on Human Rights, Slavery Conventions and other conventions related to children, women, racial discrimination and torture. These instruments also contain provision regarding the protection and promotion of children's rights. Generally, child rights include their rights to life, rights to education, rights to food, rights to health, rights to freedom, rights to water, rights to protection and security, rights to identity etc. Interpretations of children's rights range from allowing children the capacity for autonomous action to the enforcement of children being physically, mentally and emotionally free from abuse, though what constitutes abuse is a matter of debate. Other definitions include the rights to care and nurturing (Lieten, 2009). Child labour itself is the abuse of child rights. Furthermore the children who are in the condition of labour are treated inhumanly and forced to live miserable life.

As children are the pillar of the society and the future of the country, in order to make positive impacts on their lives it is necessary to eliminate violation against children by promoting their potentiality through the protection of their rights. Anthropological lens promotes universal human rights that help determine the extent to which we appreciate children's relative value (Tilley, 2000). The Constitution of Nepal 2015, the Labour Act 1992, the Children's Act 1992 and the Child Labour Prohibition and Regulation Act 2000 all have strict provisions to prohibit child labour under the age of 16 in Nepal. Child labour in any system is heinous and illegal act as per the Child Labour Act 2000, but it has not received the same amount of attention. A child bench has also been established as an enforcement mechanism to punish child abuses and offenders of the existing national legislation of children. But despite all the programs of action being carried out, the problem persists primarily due to the absence of proper enforcement and implementation of these laws. However, research on barriers to the weak implementation of the law, apart from conjectures indicating the lack of political will, is almost non-existent.

With the increasing capitalization process in most of the urban areas of Nepal, the population is increasing, new business complexes are being established, more hotels and restaurants are opened and along with it new way of child labour exploitation is emerging in Pokhara. Based on the tribulations of child labourers, this current research revolves around child labourers working in hotels and restaurants and attempts to explore the existing veracities of child labourers in hotels and restaurants of Pokhara. The key objective of this paper is to assess the causes and factors that compelled children's entry into child labour and to analyse the state of child rights.

\section{Data and Methods}

A Survey on child labour in Pokhara Metropolitan by Dharel and Bhattarai (2012) depicts that the concentration of child labourers is extremely high in the main commercial centres of Pokhara viz. Prithvi Chowk especially old bus park area, Nagdhunga, Srijana Chowk , Baglung Bus Park, Amarsing Chowk etc. According to this survey, the number of child labourers in the whole Pokhara-Lekhnath Metropolitan in all sectors is in the range between 2,032 and 3,594 children and among them 41 percent are below 16 years old. But there is no specific data of child labourers working in different sectors like hotels, restaurants,

Janapriya Journal of Interdisciplinary Studies (Jjis), volume VIII, 2019 
construction sites, domestic servants etc. Guided by the anthropological theoretical perspectives of Exploitation (Ritzer, 1983) and Structural-Functionalism (Pritchard 1962, Nadel 1957, Brown, 1940) and the philosophical principles of Positivist and Interpretivist tradition, which Chhetri (1992) terms as 'combination of anthropological and survey method', both qualitative and quantitative approaches were used in this study. The field study was conducted in a rigorous field study period during December 2-30, 2018. Using the quantitative survey method, at first, listing were done in hotels and restaurants of Prithvi Chowk inc. Old Bus Park area, Nagdhunga and Srijana Chowk to identify eligible child labourers (children below 16 years of age) and 130 child labourers (69 boys and 61 girls) were found eligible from 32 restaurants and 20 hotels of Prithvi Chowk (inc. old bus park), Nagdhunga and Srijana Chowk areas. From these, as per purposive random sampling, 80 child labourers (44 boys and 36 girls) i.e. 80 children were selected for the study. Of them, 82.5 percent were literate and had multiethnic composition comprising Janajati 45 (56.25\%) percent, Dalit 16 (20\%), Chhetri 11 (13.75\%), Brahmin 8 (10\%). Around 26.25 of them were from villages/poor communities of Kaski, Chitwan, Tanahun, Gorkha, Dhading and Syangja with age ranging from below 10 to 15 years. Survey method was used to collect quantitative information which supplemented the qualitative information collected through interviews with child labourers and restaurant/hotel employers, direct observation and case studies (altogether seven) on personal experiences, valuation of child rights, relationships and lifestyle. There were various difficulties and challenges in collecting data on such socially existing but legally illicit sadistic phenomenon as child labour. The first challenge was to persuade the child labourers to get time and to provide real information separately on their plight. The second challenge was to get the approval of the hotel/restaurant employer. For this, a generic assessment checklist was designed on child labourers' plight/human rights and pre-test was consummated on ten child-labourers employed in four hotels/restaurants of Old Bus Park and Nagdhunga that assisted in maintaining the consistency of reliability across time, items and the respondents. This facilitated in assisting validation of the measurement tools so that to represent the variables they are intended to. Ethical approval in the form of verbal consent and assurance was obtained from each respondent (child labourer and hotel/restaurant employer) before administering the interview and each respondent was convinced of the confidentiality of their identity. No higher statistical tools and methods were used to analyze and interpret the findings. The quantitative data has been treated in terms of frequencies and percentage.

\section{Results and Discussion}

Occupation is a person's usual or principle work or business, especially as a means of earning a living (Foster, 1996). Majority (47\%) of child labourers family were engaged with agriculture, 30 percent had their parents in wage labour, small business $(6.25 \%)$, and abroad employment 5\%. Subsistence agriculture with traditional agriculture system and small landholding is the major feature of their lifeline. Around 71.25 percent of child labourers were from poor families. Childhood model claims that children are a part of social structure but poverty makes them out of their social structure (James et al. 1998). To escape from poverty and to find a better life children are pushed towards child labour.

Around 67.5 percent had their both parents alive, 13.75 percent had their mother dead, 10 percent had their both parents' dead and 10 percent had their father died. About 55 percent child labours parents were living separately and 45 percent had their parents living together at home. About 48.75 percent of the child labourers' parents were illiterate. Because of illiteracy and lack of parental awareness, children did not get proper guidance.

Family size is a strong contributing factor to child labour. Around 48.75 percent of child labourer's family size was more than eight members, whereas 32.5 percent had family size between five to eight members and 18.75 percent had family size ranging from one to four.

Janapriya Journal of Interdisciplinary Studies (Jjis), volume VIII, 2019 
Large family is one of the causes that push children into child labour. Parents of large families believe that if their children work, they can be relieved from financial burden. One case reveals.

\section{Case 1}

Kam garera pariwar lai sahayog gareko chu (I am working to support my family)

I am a 12 year old boy from Bhujel community of Kushmiswara, Baglung District. I have eight members in my family. Unable to feed the family, my father compelled me to work in a hotel near Prithvi Chowk. I wake up around 5 am and start my duty and it lasts around $10 \mathrm{pm}$. My father takes my salary from the employer. My employer's wife is rigid and difficult to tolerate. Sometimes customers behave me inhumanly and scold me. To contribute my huge family and to survive, I have no option, but to work here.

\section{Domestic Violence in Family}

Domestic violence is a forced pattern of behaviour in any relationship that is used to gain or maintain power and control over an individual that includes any behaviour that is meant to threaten, intimidate, frighten, manipulate, harm, humiliate, or falsely accuse (Paul, 2006). Table below illustrates the lashing incidents of domestic violence faced by 23 children who faced domestic violence at home that pushed them to child labour.

Table 1

Incidents of Domestic Violence

\begin{tabular}{lcc}
\hline \multicolumn{1}{c}{ Incidents } & Number of Child labourer & Percentage \\
\hline Mother Eloped and Family Disturbed & 3 & 13.05 \\
Harassment/Torture of Stepmother & 9 & 39.13 \\
Quarrelling of Parents & 4 & 17.39 \\
Parents Separation/Affliction by Single Parent & 7 & 30.43 \\
Total & 23 & 100 \\
\hline
\end{tabular}

Source: Field Survey, 2018

Among them, 39.13 percent child labourers were pushed to child labour because of stepmother's harassment and torture, 30.43 percent because of parents' separation and affliction by single parent, similarly 17.39 were pressed to child labour because of quarrelling of parents and lastly 13.05 because of mother's elopement and disturbance in family. This confirms that domestic violence and family dysfunction are the forceful factors of child labour. Structural Functional theory of Brown (1940) claims that society is an organized arrangement of parts and disturbance in parts (family) creates chaos. Family breakdown breaks a child and push towards labour. Domestic violence may occur between adults or between adults and children (Chevette, 2003). Many of the child labourers were abused, tortured and bruised by their step mother. Case presented below presents the plight of a boy who was a victim of domestic violence as beatings and abuse that pushed him to child labour.

\section{Case 2}

(Poila gayeki ko choro vayeko le balshramik vaye (Become a child labour being the son of eloped mother)

I'm a 13 year old Gurung boy from Lumle, Kaski. My mother eloped and my father married another woman. My step mother used to torture me because I was the son of an eloped mother. Feeling unsecured I started working as a dishwasher in a restaurant at Nagdhunga. I work almost 15 hours a day; don't get leave. Instead they don't believe when I am sick instead blame me of being deceitful. I have to hide my pain and cry in isolation. My stepmother knows that I have been working and she has managed to get my salary. I am suffering because of my parents' behaviour that forced me to child labour.

Janapriya Journal of Interdisciplinary Studies (Jjis), volume VIII, 2019 


\section{Child Labour, Child Rights and Employer Nexus}

Child labourers plight are steadfastly associated to employers and their dealings to child worker in the matters of education, nature of work, salary, leisure, health, violence etc that verify the condition of child rights. If the employer is someway kind and conscious about child rights, the child labourers get congenial environment in work and if not they can be behaved inhumanly. The capability approach of Amartya Sen (1999) makes advocacy for welfare economics as an alternative to the understanding and protection of child rights.

\section{Right to Education}

The right to education is vital for the economic, social and cultural development of all societies that contributes to the flourishing of individuality through the enhancement of social and professional integration (UNESCO, 2005). Basu (1999) argues that education is a human right which ought to be accessible to everyone, without any discrimination. Almost 92.5 percent of the child labourers were not allowed access to school by employer; 7.5 percent children who were offered schooling by employer were reluctant to go to school. Lack of awareness and tough grind at work place are the reasons behind their reluctance. Child labourers i.e. 77.5 percent were willing to go to school if they get a congenial working environment.

\section{Nature of Work}

Almost two third of the child labourers i.e. 70 percent had no fixed work, they perform many activities throughout the day, 20 percent of the child labourers were washing dishes, similarly 13.75 percent were cleaning, likewise 8.75 percent were cooking food and 6.25 percent were washing clothes items.

Table 2

Nature of Work

\begin{tabular}{lcc}
\multicolumn{1}{c}{ Nature of Work } & Number of Child labourers & Percentage \\
\hline Washing Dishes & 16 & 20 \\
Cooking Food & 7 & 8.75 \\
Washing Cloths Items & 5 & 6.25 \\
Cleaning & 11 & 13.75 \\
All of the Above & 41 & 51.25 \\
Total & 80 & 100 \\
\hline
\end{tabular}

Source: Field Survey, 2018

Child Labour Act of Nepal 2056 BS clarifies that no child shall be engaged in work for more than six hours a day and more than thirty-six hours in a week either with or without additional remuneration. But most of the child labourers $(81.25 \%)$ worked more than 12 hours everyday while 12.5 percent worked 8-12 hours a day and only 6.25 percent had worked between 6-8 hours. These confirm that employers are ignoring the Child Labour Act by forcing overwork. Many child labourers have work routine of before 5.00 a.m. morning to between 10-11 p.m. evening and their work hours is between 17 to 18 hours a day. They are given limited time for eating; they are expected to be on duty at right time if not they are scolded and abused.

\section{Salary Received}

Contrary to Child Labour Act of Nepal 2056 BS, many child labourers bear the injustice of not paid or fixed their wages. The theory of exploitation claims that exploitation is rooted in society and economic system itself and such tendency is plausible among the child labourers. 
Prakash Upadhyay

Table 3

Wages Received by Child Labourers

\begin{tabular}{lcc}
\hline \multicolumn{1}{c}{ Nature of Wages } & Number of Child labourers & Percentage \\
\hline Paid & 25 & 31.25 \\
Not paid & 35 & 43.75 \\
Not fixed & 20 & 25 \\
Total & 80 & 100 \\
\hline
\end{tabular}

Source: Field Survey, 2018

On wages, 43.75 percent child labourers were not paid at all. About 40 percent of child labourers got Rs. 1500 to 2500 as monthly salary; similarly 32 percent got monthly Rs. 500 to Rs.1500. Most child labourers are not paid or do not have fix monthly salary and those who get salary are not satisfied because the salary is very low compared to their hard labour. About 44 percent labourers received salary half yearly; similarly 28 percent received salary tri-monthly, 20 percent of them received salary annually and only 8 percent received regular salary. The employers are not following the job rules properly and are paying wages at their will. There is no any government monitoring unit to monitor the salary payment of child workers because child labour in itself is illegal and government officials are reluctant to accept the existing phenomenon of child labour.

\section{Case 3}

Bina talab kam gardai chu ( I am working without any salary)

I'm a 14 year old Tamang boy from Phulkharka village of Dhading district. I lost my father in my childhood. I work in a restaurant at Nagdhunga as a dishwasher. I have not received a penny this year and if I asked to my employer he says 'Why do you need money?' You are living and eating here; I will give you when you need.' I don't have money even to escape and return home. I have to work around twelve hours a day. I have no option except to work here.

\section{Health and Sanitation}

Health is fundamental human rights (WHO, 1948). However, 82.5 percent of the child labourers had not got health facility when sick. It is a violation of child rights on the part of employers intricately linked with the theory of exploitation. Among the 17.5 percent child labourers who got health facilities, 35.71 percent got hygienic food while they were ill, 28.57 percent got rest when ill, 21.43 percent got hospital check-up and 14.29 percent got medical expenses while they were sick. However, in the cases of 82.5 percent child labourers, the basic needs of health facilities were bluntly ignored by employer. One case study unveils.

\section{Case 4}

\section{Bottle le hirkayeko ghau afai puriyo (Injury created by bottle healed naturally)}

I am a 12 year old Tharu girl from Chitwan. Due to stark poverty I started working as a dishwasher in a restaurant at Prithvi Chowk. I have to work from early morning to late evening. I am provided with a little amount of money but not in monthly basis. I can neither complain nor leave the hotel because I have to survive. My mistress scolds me and punishes me for broken plate and glass. Once she hit me with a broken bottle and I was badly injured but with no treatment. My injury healed naturally but it was painful and I cried a lot. I want to be free but I do not know where to go and what to do?

Good and balanced food, proper shelter, education, clothing, clean water etc. are the fundamental child rights. But only 7.5 percent of child labourers were given the same food as of their employer, 55 percent were getting low-quality (decayed/rotten) food. Around 43.75 percent child labourers were wearing the clothes already used by the employer's family

Janapriya Journal of Interdisciplinary Studies (Jjis), volume VIII, 2019 
member, 30 percent of them were in rags, whereas 22.5 percent were given cheap clothes to wear. Only 3.75 percent of the child labourers were provided clean, clothes of normal quality. It was observed that most children were filthy.

Violence and Brutality on Child Labourer

Majority of the child labourers 83.75 were treated badly. Around 50.75 percent of the child labourers were misbehaved and treated brutally by their employers, 28.36 percent were misbehaved by customers and 20.89 percent were ill-treated by senior staff. Most of child labourers i.e. 43.28 percent were bruised by heavy work burden, 31.35 percent of them were beaten and their hair pulled and, 25.37 percent child labourers were abused all time for minor offence or without any reasons. They were scolded by employers and were blamed as lazy and inefficient. Child labourers are always in panic and terrible condition. Table 4 reveals physical injuries and mutilations of 27 child workers caused by beatings and incessant work.

Table 4

Violence on Child Labourer

\begin{tabular}{lcc}
\multicolumn{1}{c}{ Consequences } & Number of Child labourers & Percentage \\
\hline Physical Injuries & 12 & 15 \\
Growth Deficiency & 45 & 56.25 \\
Long Term Health Problem/Trauma & 6 & 7.5 \\
Exhaustion and Malnutrition & 27 & 33.75 \\
\hline
\end{tabular}

Source: Field Survey, 2018

It was observed that many of the child labourers were physically injured e.g. fire burn, torn palm, legs and fingers. Almost 15 percent of the child labourers were physically injured, followed by growth deficiency (56.25\%), long term health problem/trauma (7.5), exhaustion and malnourishment $(33.75 \%)$. Many were pale faced and mal-nourished which can impinge on their adult life. Numerous child labourers are irritated, traumatized, depressed and have anti-social thinking due to incessant oppression and work burden. Taking child labourers as means of profit, the employers pressurize them for over-work. One case study reveals the bitter experience of a child labourer who escaped from his home but was badly bruised by his hotel employer.

\section{Case 5}

Sarir bhari hirkayeko nil dam cha (My body is full of cane beaten wounds)

I am a 12 year old Tharu boy from a poor Tharu family of Meghauli, Chitwan. Because of hardships I escaped from home and started to work in a hotel at Prithvi Chowk. I wake up early in the morning and start my daily work. I have to perform various duties: dishwashing, cleaning, shopping, waiter etc without any leave. My employer is rude. When I make mistakes, he scolds me and beat me badly. My body is full of wounds beaten by cane. Under this situation, I remember my family. I am fed up with overload and violent behaviour of the employer. My dream of good life and education has been shattered.

Commoditization of child workers is pervasive. Employers pressurize the child labourers to gratify their customers that results in sexual harassment and mental trauma. The case of a girl child labourer who has been sexually harassed discloses the dark aspect of child labour.

Case 6

Grahak ra sahu le mero gopya anga chunchan (Customer and employer touch my sensitive organ)

Janapriya Journal of Interdisciplinary Studies (Jjis), volume VIII, 2019 
I am a 15 year old Dalit girl from Syangja working in a restaurant at old bus park. On many occasions in the evening time many alcoholic customers' tries to touch my sensible organ pretending as if they are showing love. I cannot deny it because I'm supposed to gratify the customers. Not only the visitors but also my employer sometimes touches me knowingly in my private parts. I cannot express it because he says me he can do whatever he likes. I am always in panic. I want to be free from such work but I have no choice except accepting my destiny.

\section{Rehabilitation}

Most of the child labourers i.e. almost 90 percent were willing to change their profession and rehabilitate if they get any alternative. Most of the child labourers are not involved in this work by desire but by compulsion. Only 10 percent of the child labourers were contented with their profession and want to stay where they are. Among those who want to rehabilitate, 47.22 percent child labourers wanted to continue their study, 35 percent wished to go home and 12.5 percent want to shift to other works. Most of the children wanted to continue their study.

\section{Relations with Employer}

A strong, healthy relationship can be one of the best supports in life. However, if relationship isn't working, it can also be a tremendous drain. Majority of the child labourers (73.75 percent) had unhealthy and stressful relationship with employers i.e. they were dissatisfied with their employer's treatment. Only 13.75 percent child labourers had good relations with their employer.

Table 5

Relation of Child Labourer with Employer

\begin{tabular}{lcc}
\hline \multicolumn{1}{c}{ Response } & $\begin{array}{c}\text { Number of Child } \\
\text { labourers }\end{array}$ & Percentage \\
\hline Good Relation / Satisfied & 11 & 13.75 \\
Unhealthy Relation / Dissatisfied & 59 & 73.75 \\
No answer & 10 & 12.5 \\
Total & 80 & 100 \\
\hline
\end{tabular}

Source: Field Survey, 2018

Amid unhealthy relations, child labourers are deprived of love, care and attention. One case exposes the bitter verity of a child labourer's relation with her employer.

\section{Case 7}

Mero sahu marae pani hunthiyo (I wish my employer would have been dead)

I am 15 years old girl from Bishwokarma family of Myagdi District. My father is in gulf country and at home my stepmother used to beat and torture me hence I escaped to Pokhara. Now I am working as a waiter in a restaurant at Srijana Chowk. I have to wake up at 4 am in the morning and work as dishwasher almost up to 11pm. Though I'm habituated with my job it makes me broken down every day. I don't get rest even during my menstruation period, when tired and feverish, I did not get rest. They provide me paracetamol and let me work. If I don't work they scold me. I wish my employer would have been dead only then I will be free.

\section{Employers Preference and Perception on Child Labour and Child Rights}

Employers were preferring children as a worker because of easy access of child labourers. Most of the employers i.e. 30 percent preferred children because they did not demand high wage and other facilities. Similarly 23.75 percent employers preferred children because they perform activities consciously, 22.5 percent preferred children because they were easy going. Likewise, 7.5 percent employers favoured child labourer because they had little chance of involvement in activities as theft. Lastly, 16.25 percent employers preferred children because 
of all of the above reasons. It is an irony that child labourer is valuable for employer but the life of child labourer is worthless. Most employers do not know about child rights.

Table 6

Restaurant/Hotel employers Perception on Child Rights

\begin{tabular}{lcc}
\hline \multicolumn{1}{c}{ Perception } & $\begin{array}{c}\text { Number of Child } \\
\text { labourers }\end{array}$ & Percentage \\
\hline Partially know about Child Rights & 18 & 22.5 \\
Do not know about Child Rights & 39 & 48.75 \\
Aware about Child Rights & 23 & 28.75 \\
Total & $\mathbf{8 0}$ & $\mathbf{1 0 0}$ \\
\hline
\end{tabular}

Source: Field Survey 2018

Almost half of the employers i.e. 48.75 percent were unknown about child rights, only 28.75 percent were aware on child rights and lastly, 22.5 percent partially know about child rights. Many employers think that they were not violating the child rights but they were protecting it as they provide job opportunity and means of survival to the children, which mean that they are uninformed about the child rights and child labour. This depicts the level of awareness of employers, or they may not be telling the truth in the fear of legal prosecution.

Broadly, the relationship between child labour, child rights and employers depicts a dismal stipulation, full of strains.... where child labourers are compelled to work and survive in an inhuman condition with very little or no child rights. Despite this, employers prefer a child labourer...correlated amicably with the theory of exploitation which holds the notion that the capitalist compensates the labourers enough for his labour power to reproduce commodity.

\section{Conclusion}

The wicked problem of child labour is the immediate result of family structure and its dysfunction allied to structural - functionalist perspective which hub on healthy family function under a strong bond. Child labourers are stuck in deplorable work-with long work hours and 3D (difficult, dangerous and dirty) works, but with meagre salary or even unpaid. Deprived of their basic child rights and shattered budding childhood dreams, their childhood has been stolen by the grown-up adult....the hotel and restaurant employer and even their parents. The dreams of education and a balanced normal childhood have crushed under the shackle of child labour. It is a fascinating paradox that major bulks of hotel and restaurant employers were unknown about child rights and the harsh veracity that they stole child labourer's childhood and child rights. The concerned government authorities are ignorant to this illegal theft. The irony is that there is no government data on the exact number of child labourers in hotels and restaurants of Pokhara.

Theory of exploitation argues that the capitalist mode of production apart from the commodity mode of production is not only the accumulation of money; but the use of labour power as a commodity to create more value. Hotel/restaurant employers are exploiting child labourers to accumulate surplus money and hence violated Child Labour Act of Nepal 2056 BS. Children needs fair environment for their overall growth but this study dig out very unjust and disgusting life of child labour. Ballet et al. (2006) apply the capability approach to child labour issue, focusing on Amartya Sen's (1999) concepts of substantive opportunities and freedom of processes, which state that the end must be achieved through the most efficient and available means of sustaining economic life, security and welfare of people. Hence, a combination of stringent policies that might contribute complete elimination of child labour could be employment generation schemes that lead to economic prosperity for the household, compulsory schooling for children, a school enrolment subsidy and adult literacy campaigns that increase community or social awareness, especially among adult women. Nepal's rigid social structure has also contributed to child labour, and there are severe inequalities in

Janapriya Journal of Interdisciplinary Studies (Jjis), volume VIII, 2019 
society that seem to have contributed to widespread poverty, which in turn has forced parents to send their children to become part of the workforce. Child labour and child rights are controversial. Child labour is illegal, however government monitoring cell is necessary to monitor the regular salary payment of child workers--may be through banking payment.

Acknowledgement: I am indebted to Prof. Vikash K.C. for his encouragement and prolific support to enhance my professional/academic career. This research work is a venture of the researcher under the aegis of M.A. anthropology thesis writing students' research/fieldwork program, Prithvi Narayan Campus, Tribhuvan University, Nepal.

\section{References}

Ballet, J., Bhukuth, A., \& Radja, K. (2006). Child Labour, Human Rights and the Capability Approach. Retrieved 20 January 2010 from http://www.capabilityapproach.com/pubs/3

Basu, K. (1999). Child Labour: Cause, Consequence, and Cure, with Remarks on International Labour Standards. Journal of Economic Literature 37(3):1083-1119.

Brown, R. (1940). On Social Structure. Journal of the Royal Anthropological Institute of Great Britain and Ireland 70 (1):1-12.

Chhetri RB. (1992). Adaptation of Tibetan refugees in Pokhara, Nepal: A study on persistence and change. $\mathrm{Ph}$. D. Dissertation submitted to University of Hawaii.

Chevette, A. (2003). Domestic Violence and Sociology: Definition \& Effects. https://study.com/.../lesson/domestic-violence-and-sociology-definition-effects-quiz.ht.

Child Labour (prohibition and regulation) Act 2056 (2000). Kathmandu, Nepal Law Commission.

CWIN (2000). The State of the Rights of the Children in Nepal, National Report.

Dharel, M., \& Bhattarai, R. (2012). Child Labour in Pokhara and Lekhnath City. Nepal Pokhara Chamber of Commerce and Industry and Lekhnath Chamber of Commerce and Industry.

Foster J. (1996). Why does Child Labour occur? Retrieved 2 January 2010 from http://www.earlham.edu/ pols/globalprobs/children/Amye.html.

ILO (2004). Child Labour. International Labour Office Geneva.

ILO/IPEC (2006). Combating the worst forms of child labour in Nepal, An update on Facts and Figures, Achievements and Challenges within the Seven Sectors Covered by the IPEC Nepal Core TBP Project. Kathmandu: ILO.

James, A., Jenks, C., \& Prout, A. (1998). Theorising Childhood. Cambridge: Polity Press.

Lieten, GK (2009). Child Labour and Child Rights. Dhaka: University Press Limited.

Nadel, S. F. (1957). The Theory of Social Structure. Cambridge University Press.

Janapriya Journal of Interdisciplinary Studies (Jjis), volume VIII, 2019 
Prakash Upadhyay

Nepal Child Labour Report (2008). Nepal Labour Force Survey. International Labour Organization, International Programme on Elimination of child Labour (IPEC), Central Bureau of Statistics of Nepal- Kathmandu: ILO.

Paul, James (2006). Globalization and Violence, Transnational Conflict. Sage Publications. London.

Pritchard, Evans (1962). Social Anthropology and Other Essays. New York: The Free Press.

Ritzer, G., (1983). Sociological Theory. New York, Knopf Inc.

Sainju, B. (2003). Child labour in restaurants and tea shops in Nepal, Kathmandu: CONCERN-Nepal.

Sen, A. (1999). Development as Freedom. Oxford, Oxford University Press.

Tilley, J.J. (2000). Cultural Relativism. Human Rights Quarterly 22 (2):501-547.

UNESCO (2005). Education for all global monitoring report. Literacy for Life Paris: UNESCO.

UNICEF (2007). The state of the world's children 2007: women and children. The Double Dividend of Gender Equality. New York, UNICEF.

Janapriya Journal of Interdisciplinary Studies (Jjis), volume VIII, 2019 